\title{
TINDAKAN PENCEGAHAN MALARIA DI DESA SUDOROGO KECAMATAN KALIGESING KABUPATEN PURWOREJO
}

\author{
THE PREVENTION OF MALARIA AT SUDOROGO VILLAGE KALIGESING \\ DISTRICT OF PURWOREJO
}

\author{
Restu Alami, Retno Adriyani \\ Departemen Kesehatan Lingkungan \\ Himpunan Ahli Kesehatan Lingkungan Indonesia \\ Email: restu.alami@yahoo.co.id
}

\begin{abstract}
Malaria is a parasitic disease that is still a public health problem in Indonesia. Public awareness of the dangers of malaria will affect the precautions taken. This study aimed to analyze the measures of prevention of malaria in the Sudorogo village Kaligesing District of Purworejo. This study used a case control approach. Sample of this study consisted of 20 cases and 20 controls were taken using simple random sampling technique. The study was conducted from July 2016 to January 2017. The instrument that used in this research was questionnaires and observation sheets. The collected data were analyzed using simple logistic regression. The results of the analysis, indicated that the society actions are habit to stayed outside home in the evening; conducting environmental health habits; habit of not wearing mosquito repellent during the night; habit of not wearing repellent when outdoors activity at night; and the habit of not wearing long sleeves and long pants when out at night did not show any significant correlations with the incidence of malaria in the area of research. Variables that showed a significant correlation with the incidence of malaria in the area of research is the habit of not using mosquito nets while sleeping at night with a p value of $0.012(95 \%$ CI 1.529 to 31.377). The conclusion of this study was there is correlation between habit of not using mosquito nets while sleeping with the incidence of malaria in the Sudorogo village Kaligesing District of Purworejo.
\end{abstract}

Keywords: preventive action, the incidence of malaria

\begin{abstract}
Abstrak: Malaria adalah penyakit parasit yang masih menjadi permasalahan kesehatan masyarakat di Indonesia. Kesadaran masyarakat terhadap bahaya malaria akan mempengaruhi tindakan pencegahan yang dilakukan. Penelitian ini bertujuan untuk menganalisis tindakan pencegahan malaria di Desa Sudorogo Kecamatan Kaligesing Kabupaten Purworejo. Penelitian ini menggunakan pendekatan case control. Sampel penelitian sebesar 20 kasus dan 20 kontrol yang diperoleh dengan simple random sampling. Penelitian dilakukan mulai bulan Juli 2016 sampai Januari 2017. Instrumen penelitian yang digunakan yaitu kuesioner dan lembar observasi. Data yang telah terkumpul dianalisis menggunakan uji regresi logistik sederhana. Hasil analisis mengindikasikan bahwa tindakan masyarakat yang meliputi kebiasaan berada di luar rumah malam hari; kebiasaan melakukan kegiatan penyehatan lingkungan; kebiasaan tidak memakai obat anti nyamuk saat tidur malam; kebiasaan tidak memakai repellent saat aktivitas di luar rumah malam hari; dan kebiasaan tidak memakai baju lengan panjang dan celana panjang saat keluar rumah malam hari tidak menunjukkan adanya hubungan yang bermakna dengan kejadian malaria di wilayah penelitian. Variabel yang menunjukkan adanya hubungan yang bermakna dengan kejadian malaria di wilayah penelitian adalah kebiasaan tidak memakai kelambu pada saat tidur malam dengan nilai $p$ sebesar 0,012 (95\% CI 1,529-31,377). Kesimpulan dalam penelitian ini adalah kebiasaan tidak memakai kelambu saat tidur malam merupakan faktor yang berhubungan dengan kejadian malaria di Desa Sudorogo Kecamatan Kaligesing Kabupaten Purworejo.
\end{abstract}

Kata kunci: tindakan pencegahan, kejadian malaria 


\section{PENDAHULUAN}

Penyakit parasitik terpenting di dunia yakni malaria. Satu milyar orang diperkirakan berisiko tertular penyakit ini dan 2,5 juta penderita malaria diperkirakan meninggal dunia setiap tahun. Penyakit malaria lebih banyak terjadi pada anak-anak berusia dibawah 5 tahun (Soedarto, 2009). Widoyono (2011) menambahkan bahwa penyakit malaria sudah ada sejak 3000 tahun yang lalu. Penyebab dari penyakit malaria adalah parasit Plasmodium, sedangkan penularannya pada manusia diperantarai oleh nyamuk Anopheles betina. Penyakit malaria ini masih menjadi permasalahan kesehatan yang besar baik di daerah tropis maupun subtropis seperti di Brasil, Asia Tenggara dan seluruh sub-Sahara Afrika.

Data dari Badan Kesehatan Dunia, World Health Organization atau WHO (2015) menunjukkan bahwa jumlah kasus malaria secara global telah turun dari perkiraan 262 juta kasus pada tahun 2000 menjadi 214 juta kasus pada tahun 2015. Jumlah kasus malaria terbanyak ada di Afrika yaitu sebesar $88 \%$. Kematian pada balita yang disebabkan oleh malaria juga diperkirakan telah menurun dari 723 ribu kematian pada tahun 2000 menjadi 306 ribu kematian pada tahun 2015. Penurunan jumlah kematian ini telah memberikan perkembangan yang besar terhadap kemajuan pencapaian target Millennium Development Goals (MDGs) poin 4 yaitu mengurangi angka kematian balita $2 / 3$ dari tahun 1990-2015. Namun demikian, penyakit malaria ini masih menjadi pembunuh utama bagi anak-anak terutama di wilayah sub-Sahara Afrika dengan kematian terjadi setiap 2 menit pada 1 anak.

Permasalahan penyakit malaria di Indonesia cenderung menurun. Terdapat 465.764 kasus positif malaria di tahun 2010 dan pada tahun 2015 telah menurun menjadi 209.413 kasus (Anonim, 2016).

Direktorat Jenderal (Dirjen) Pengendalian Penyakit dan Penyehatan Lingkungan (2015) menuturkan bahwa penyakit malaria ini masih menjadi permasalahan kesehatan masyarakat. Disamping itu, penyakit malaria ini juga menjadi tujuan ke-6 MDGs dan Rencana Pembangunan Jangka Menengah Nasional
(RPJMN) Tahun 2015-2019. Pada tahun 2019 nanti, diharapkan 400 kabupaten/kota telah mencapai angka kesakitan $<1$ per 1000 penduduk (\%o) dan 300 kabupaten/kota telah mencapai tahap eliminasi malaria.

Sutriyanto (2014) melaporkan hasil wawancaranya dengan Menteri Kesehatan Nafsiah Mboi dalam Tribunnews.com bahwa hingga tahun 2014, dari 595 kabupaten/kota sebanyak 200 kabupaten kota dengan total penduduk 132,5 juta orang telah mencapai tahap eliminasi malaria yang artinya tidak ditemukan kasus malaria. Kemenkes (2016) menambahkan, sampai pada bulan Desember 2015,terdapat 45 kabupaten/ kota telah mencapai tahap akselerasi, 90 kabupaten/kota pada tahap intensifikasi dan 379 kabupaten/kota pada tahap pre eliminasi. Sebanyak 232 kabupaten/kota dari 379 kabupaten/kota yang ada pada tahap pre eliminasi, telah dinyatakan eliminasi. Pernyataan serupa juga diungkapkan oleh Subekti (2016) melalui www.pojoksatu.id, bahwa Sekretaris Ditjen Pencegahan dan Pengendalian Penyakit (P2P) Kemenkes Desak Made Wismarini mengatakan, lebih dari 80 persen kabupaten/kota di Jawa, Bali, dan Sumatera Barat telah mencapai eliminasi malaria. Hal ini dibuktikan dengan penduduk berisiko tinggi malaria telah mendapat perlindungan kelambu anti nyamuk di daerah endemis tinggi hingga mencapai 87 persen.

Provinsi Jawa Tengah merupakan salah satu daerah yang tidak luput dari kasus malaria. Angka kesakitan malaria di Provinsi Jawa Tengah pada tahun 2014 mencapai $0,05 \%$ penduduk. Angka ini sudah mencapai target nasional karena $<1 \%$. Akan tetapi masih terdapat kasus indigenous di 5 kabupaten yaitu Purworejo, Banjarnegara, Purbalingga, Banyumas dan Kebumen (Dinkes Jateng, 2014). Pada tahun 2015, angka kesakitan malaria atau yang lebih dikenal dengan istilah Annual Paracite Incidence (API) di Provinsi Jawa Tengah meningkat menjadi $0,06 \%$ dengan jumlah kasus sebanyak 2.190 kasus. Pada tahun 2015 juga masih terdapat kasus indigenous di 4 kabupaten yaitu, Kabupaten Purworejo (API 1,96\%), Kabupaten Banjarnegara (API 0,35\%), Kabupaten Magelang (API 0,13\%) dan Kabupaten Purbalingga (API 
$0,04 \%$ ). Upaya pengendalian malaria ini terbentur adanya beberapa kendala, yakni (1) Mobilitas penduduk yang tinggi, (2) Jumlah Juru Malaria Desa (JMD) berkurang dan frekuensi kunjungan JMD juga menurun, (3) Komitmen stakeholder dalam eliminasi malaria masih kurang, (4) Tim Gebrak Malaria belum optimal, dan (5) Pemeriksaan sediaan darah secara mikroskopis belum dapat dilakukan oleh semua rumah sakit.

Kabupaten Purworejo adalah salah satu kabupaten di Provinsi Jawa Tengah yang selalu menyumbangkan kasus malaria setiap tahunnya. Berdasarkan data dari Dinas Kesehatan Kabupaten (DKK) Purworejo $(2013 ; 2014)$ serta data dari Dinas Kesehatan Provinsi Jawa Tengah (Dinkes Jateng) (2015), Kabupaten Purworejo merupakan kabupaten yang menyumbangkan jumlah kasus malaria terbanyak di Provinsi Jawa Tengah. Jumlah kasus malaria di Kabupaten Purworejo meningkat dari tahun 2013 sampai dengan tahun 2015. Pada tahun 2013 tercatat ada 712 kasus malaria dengan API $0,98 \%$. Selanjutnya pada tahun 2014 meningkat menjadi 803 kasus dengan API 1,13\% dan pada tahun 2015 kembali meningkat menjadi 1.411 kasus dengan angka kesakitan atau API mencapai 1,96\%. Berdasarkan hal tersebut, dapat disimpulkan bahwa angka kesakitan malaria Kabupaten Purworejo pada tahun 2014 dan 2015 belum memenuhi target nasional sebesar $<1$ per 1000 penduduk. Pada Rencana Kerja Pembangunan Daerah (RKPD) tahun 2016, Kabupaten Purworejo menargetkan capaian untuk angka kesakitan malaria (API) sebesar 0,9 per $1000(\%)$ penduduk (Pemerintah Kabupaten Purworejo, 2016).

Data register malaria yang didapatkan dari bidang Pemberantasan Penyakit dan Penyehatan Lingkungan (P2PL) DKK Purworejo (2016) dan data dari Puskesmas Kaligesing (2016) menunjukkan terdapat 304 kasus malaria di wilayah Kabupaten Purworejo pada periode Januari-Juli 2016. Jumlah kasus tertinggi berada di wilayah kerja Puskesmas Kaligesing. Berdasarkan data register malaria dari Puskesmas Kaligesing (2015;2016), kenaikan jumlah kasus malaria di wilayah Puskesmas Kaligesing dari tahun 2015 sampai dengan periode Januari-Juli 2016 terjadi di tiga desa yaitu Desa Pandanrejo, Desa Pucungroto dan Desa Sudorogo. Desa Sudorogo ini merupakan desa dengan kenaikan tertinggi dan merupakan desa dengan jumlah kasus malaria tertinggi yaitu sebanyak 23 kasus. Seluruh kasus ini merupakan kasus indigenous yaitu kasus yang terjadi akibat penularan lokal atau setempat.

Berdasarkan WHO (2015) terjadinya malaria pada manusia disebabkan oleh parasit dari genus Plasmodium, yaitu Plasmodium falciparum, Plasmodium vivax, Plasmodium malariae, Plasmodium ovale dan Plasmodium knowlesi. Kemenkes (2012) membagi malaria menjadi 5 jenis, yaitu (1) Malaria falsiparum. Malaria ini disebabkan oleh Plasmodium falciparum dengan ditandai adanya demam yang muncul secara intermiten dan dapat pula kontinu. Malaria jenis ini yang seringkali menyebabkan kematian, (2) Malaria vivax yang disebabkan oleh Plasmodium vivax. Gejalanya yaitu demam yang akan berulang dengan interval bebas demam selama dua hari, (3) Malaria ovale yang penyebabnya adalah Plasmodium ovale. Gejalanya adalah demam yang berulang dengan interval bebas demam selama dua hari, (4) Malaria malariae yang disebabkan oleh Plasmodium malariae. Demam terjadi secara berulang dengan interval bebas demam selama tiga hari dan (5) Malaria knowlesi yang disebabkan oleh Plasmodium knowlesi dan ditandai dengan gejala demam intermiten dan dapat kontinu.

Parasit malaria membutuhkan dua pejamu atau host di dalam siklus hidupnya yaitu nyamuk Anopheles betina dan manusia. Fase atau tahapan seksual terjadi di dalam lambung nyamuk. Setelah nyamuk Anopheles betina menghisap darah penderita malaria, gametosit jantan dan gametosit betina kemudian akan melebur membentuk zigot. Zigot ini kemudian berkembang membentuk kista di sepanjang dinding lambung nyamuk. Kista ini kemudian pecah dan akan mengeluarkan sporozoit. Sporozoit kemudian akan bergerak menuju kelenjar ludah nyamuk dan siap untuk disuntikkan ke tubuh manusia sehat. Setelah masuk tubuh manusia, sporozoit kemudian akan ikut aliran darah dan menuju hati. Di dalam hati, sporozoit akan terus berkembang menjadi 
merozoit dan memenuhi sel hati. Merozoit tersebut akan mengeluarkan tropozoit dan menginfeksi sel darah merah ketika sel hati pecah. Fase aseksual kemudian dimulai. Tropozoit ini akan berkembang menjadi skizon. Setelah itu, skizon akan berkembang menjadi merozoit dan pecah membebaskan tropozoit. Siklus ini berlanjut sampai tiga kali. Sebagian merozoit kemudian berkembang menjadi gametosit dan bila terisap oleh nyamuk Anopheles betina, maka parasit akan melanjutkan siklus perkembangbiakan secara seksual di dalam tubuh nyamuk. Gejala malaria biasanya ditandai dengan adanya demam tinggi, sakit kepala atau pusing, menggigil dan nyeri di seluruh tubuh. Pada beberapa kejadian malaria yang lain juga disertai dengan adanya mual, muntah dan diare. Karena gejalanya hampir menyerupai gejala penyakit lainnya, maka diperlukan pemeriksaan laboratorium untuk dapat memastikannya (Kemenkes, 2011).

Diagnosis malaria dapat dilakukan dengan (1) Anamnesis yaitu dengan menanyakan keluhan kepada pasien, menanyakan riwayat sakit malaria dan minum obat malaria sebelumnya, riwayat berkunjung ke tempat endemis malaria dan riwayat tinggal di tempat endemis, (2) Melalui pemeriksaan fisik yang meliputi suhu tubuh aksiler mencapai $\geq 37,5^{\circ} \mathrm{C}$, telapak tangan dalam kondisi pucat, sklera ikterik, terjadi pembesaran pada limpa dan hati, (3) Pemeriksaan laboratorium yang meliputi pemeriksaan dengan mikroskop dan pemeriksaan dengan uji diagnostik cepat (rapid diagnostic test) (Kemenkes, 2012).

Populasi berisiko terkena penyakit malaria menurut WHO (2014), yaitu (1) Orang yang bekerja pada proyek pembangunan di daerah pedesaan seperti perkebunan, pertambangan, konstruksi bendungan, agro-kehutanan, dan lain-lain, (2) Masyarakat etnis, (3) Imigran yang berasal dari daerah endemis dan anak mereka yang tinggal di daerah non endemis kemudian kembali ke daerah endemis untuk mengunjungi saudara mereka, (4) Anakanak yang berada di daerah transmisi stabil yang belum mempunyai kekebalan, (5) Wanita hamil non imun, (6) Wanita hamil semi-imun di daerah transmisi tinggi, (7)
Wanita hamil semi-imun yang terinfeksi HIV, (8) Orang dengan HIV/AIDS, dan (9) Wisatawan internasional dari daerah non endemik.

Kondisi sehat maupun sakit dipengaruhi oleh banyak faktor. Menurut Hendrik Bloom yang dikutip oleh Asmadi (2008), status kesehatan individu dipengaruhi oleh adanya faktor keturunan, layanan kesehatan, lingkungan dan perilaku. Diantara faktor tersebut, faktor yang mempunyai dampak besar terhadap status kesehatan seseorang adalah faktor lingkungan (45\%) dan faktor perilaku (30\%). Kedua faktor ini mempunyai hubungan yang erat. Kondisi lingkungan yang sehat dapat terwujud oleh adanya perilaku masyarakat yang sehat. Sebagai contoh, penyakit demam berdarah terjadi juga akibat adanya faktor lingkungan dan perilaku masyarakat.

Perilaku merupakan salah satu faktor penting yang mempengaruhi kesehatan seseorang. Oleh karena itu, upaya intervensi terhadap faktor perilaku merupakan langkah strategis untuk dapat membina dan meningkatkan kesehatan masyarakat. Perilaku seseorang dalam menanggapi kondisi sakit atau saat terkena penyakit dapat terlihat dalam bentuk respons tertutup dan respons terbuka. Respons tertutup masih terbatas hanya sampai pada tingkatan perhatian, persepsi, pengetahuan atau kesadaran serta sikap. Misalnya seseorang sudah mengetahui tentang bahaya merokok, tetapi ia masih aktif merokok. Respons terbuka terwujud dalam bentuk tindakan nyata yang dapat diamati, seperti tidak merokok (Maulana, 2009). Notoatmodjo (2010) menambahkan bahwa sikap tidak dapat secara otomatis terwujud dalam tindakan sehari-hari. Adanya faktor pendukung seperti fasilitas dan dukungan (support) sangat dibutuhkan untuk mewujudkan sikap menjadi tindakan nyata.

Kemenkes (2014) menyebutkan bahwa tingkat kesadaran masyarakat akan bahaya malaria dapat mempengaruhi kesediaan masyarakat dalam melakukan upaya pencegahan untuk menanggulangi kemungkinan terjangkit malaria. Kesadaran masyarakat tersebut dapat dilihat dari tindakan pencegahan yang dilakukan 
seperti (1) Kebiasaan berada di luar rumah sampai larut malam, (2) Melakukan kegiatan penyehatan lingkungan, (3) Menggunakan kelambu. Tujuan dari penggunaan kelambu saat tidur adalah untuk membatasi nyamuk infektif menggigit orang yang sehat dan nyamuk yang sehat menggigit orang sakit, (4) Menggunakan insektisida rumah tangga. Insektisida rumah tangga adalah produk anti nyamuk yang sering digunakan masyarakat seperti obat anti nyamuk bakar maupun obat anti nyamuk semprot (5) Penggunaan repellent. Fungsi dari repellent ini adalah untuk menolak serangga khususnya nyamuk dan mencegah adanya kontak langsung dengan nyamuk. Repellent dikatakan baik apabila nyaman digunakan di kulit, tidak menimbulkan iritasi, tidak terasa panas atau lengket jika digunakan, dan berbahan dasar alami, (6) Penggunaan penutup badan. Penggunaan pakaian yang tertutup sangat membantu dalam mencegah gigitan nyamuk terlebih jika melakukan kegiatan di malam hari seperti memancing, ronda malam, berkemah ataupun masuk hutan, (7) Pemasangan kawat kasa pada pintu dan jendela. Upaya ini bertujuan agar nyamuk tidak masuk ke dalam rumah. Tujuan dari penelitian ini adalah untuk menganalisis tindakan pencegahan malaria di Desa Sudorogo Kecamatan Kaligesing Kabupaten Purworejo.

\section{METODE}

Penelitian ini bersifat observasional dengan pendekatan case control. Besarnya sampel terdiri dari 20 kelompok kasus dan 20 kelompok kontrol. Sampel kelompok kasus merupakan orang yang tinggal di Desa Sudorogo dan dinyatakan positif malaria berdasarkan pemeriksaan sediaan darah secara mikroskopis. Sampel kelompok kontrol adalah orang yang tinggal di Desa Sudorogo dan dinyatakan negatif malaria berdasarkan pemeriksaan sediaan darah secara mikroskopis. Pengambilan sampel dilakukan dengan simple random sampling. Penelitian dilakukan di Desa Sudorogo Kecamatan Kaligesing Kabupaten Purworejo yang dimulai pada bulan Juli 2016 sampai Januari 2017.
Data penelitian berupa data primer dan sekunder. Data primer diperoleh berdasarkan hasil wawancara dengan menggunakan kuesioner kepada responden dan observasi langsung dengan menggunakan lembar observasi. Data sekunder diperoleh melalui studi kepustakaan untuk teori dan penelitian yang mendukung, data jumlah kasus malaria dan jenis Plasmodium berasal dari Dinas Kesehatan Kabupaten Purworejo dan Puskesmas Kaligesing, data jenis vektor penular malaria di wilayah penelitian diperoleh dari wawancara dengan petugas Puskesmas Kaligesing dan data demografi wilayah penelitian diperoleh dari Badan Pusat Statistik Kabupaten Purworejo. Data yang telah diperoleh kemudian dianalisis dengan menggunakan uji regresi logistik sederhana.

\section{HASIL PENELITIAN}

Kabupaten Purworejo adalah salah satu kabupaten di provinsi Jawa Tengah. Batas wilayah sebelah utara adalah Kabupaten Wonosobo dan Magelang, sebelah barat adalah Kabupaten Kebumen, sebelah timur yaitu Daerah Istimewa Yogyakarta dan sebelah selatan adalah Samudera Indonesia. Secara topografi wilayah Kabupaten Purworejo mempunyai iklim tropis basah dengan kelembapan udara antara $70 \%-90 \%$ dan suhu antara $19^{\circ} \mathrm{C}-28^{\circ} \mathrm{C}$. Salah satu kecamatan di Kabupaten Purworejo adalah Kecamatan Kaligesing. Wilayahnya terbagi dalam 21 desa dan hampir seluruh wilayah adalah pegunungan. Luas wilayahnya adalah $74,73 \mathrm{~km}^{2}$ dengan $97 \%$ dari wilayah tersebut merupakan lahan kering dan 3\% adalah lahan sawah. Sebesar 54\% dari luas lahan kering yang tersedia dimanfaatkan masyarakat sebagai tegal atau kebun atau ladang dan sisanya sebagai bangunan atau halaman.

Desa Sudorogo merupakan bagian dari wilayah Kecamatan Kaligesing yang merupakan desa dengan jumlah kasus malaria tertinggi di Kabupaten Purworejo pada periode Januari-Juli 2016 dengan jumlah kasus sebanyak 23 kasus. Desa ini mempunyai ketinggian 344 meter diatas permukaan air laut (mdpl). Luas wilayahnya adalah $2.660 \mathrm{~km}^{2}$ dan sebagian besar dari 
wilayahnya merupakan tanah kering. Jumlah penduduk Desa Sudorogo pada tahun 2015 lebih banyak penduduk perempuan dibandingkan dengan penduduk laki-laki. Penduduk perempuan jumlahnya mencapai 670 jiwa sedangkan penduduk laki-laki berjumlah 634 jiwa. Sarana kesehatan yang terdapat di Desa Sudorogo adalah Pos Kesehatan Desa (PKD). Jumlah bangunan yang ada di Desa Sudorogo sebanyak 399 bangunan dengan 268 bangunan masih berupa bangunan tidak permanen. Mayoritas masyarakat di Desa Sudorogo memiliki ternak besar berupa kambing. Hal ini ditunjukkan dengan data bahwa terdapat 721 ekor kambing, 36 ekor domba dan 4 ekor sapi di Desa Sudorogo.

Berdasarkan Tabel 1, diketahui bahwa responden dalam penelitian ini sebagian

Tabel 1. Karakteristik Responden

\begin{tabular}{|c|c|c|c|c|}
\hline \multirow{3}{*}{ Faktor Pejamu Manusia } & \multicolumn{4}{|c|}{$\begin{array}{c}\text { Status } \\
\text { Responden }\end{array}$} \\
\hline & \multicolumn{2}{|c|}{ Sakit } & \multicolumn{2}{|c|}{$\begin{array}{c}\text { Tidak } \\
\text { sakit }\end{array}$} \\
\hline & f & $\%$ & f & $\%$ \\
\hline \multicolumn{5}{|l|}{ Umur } \\
\hline Anak-anak dibawah umur & 6 & 30 & 3 & 15 \\
\hline Pemuda & 13 & 65 & 15 & 75 \\
\hline Setengah baya & 0 & 0 & 1 & 5 \\
\hline Orang tua & 1 & 5 & 1 & 5 \\
\hline Total & 20 & 100 & 20 & 100 \\
\hline \multicolumn{5}{|l|}{ Jenis kelamin } \\
\hline Laki-laki & 12 & 60 & 9 & 45 \\
\hline Perempuan & 8 & 40 & 11 & 55 \\
\hline Total & 20 & 100 & 20 & 100 \\
\hline \multicolumn{5}{|l|}{ Tingkat pendidikan } \\
\hline Tidak sekolah/SD & 5 & 25 & 3 & 15 \\
\hline Tamat SD & 5 & 25 & 5 & 25 \\
\hline Tamat SMP & 6 & 30 & 6 & 30 \\
\hline Tamat SMA/SMK & 4 & 20 & 6 & 30 \\
\hline Total & 20 & 100 & 20 & 100 \\
\hline \multicolumn{5}{|l|}{ Pekerjaan } \\
\hline Belum/Tidak bekerja & 2 & 10 & 2 & 10 \\
\hline Pelajar & 6 & 30 & 2 & 10 \\
\hline Petani & 9 & 45 & 12 & 60 \\
\hline Pedagang & 0 & 0 & 1 & 5 \\
\hline Ibu Rumah Tangga & 3 & 15 & 3 & 15 \\
\hline Total & 20 & 100 & 20 & 100 \\
\hline \multicolumn{5}{|l|}{ Sikap } \\
\hline Baik & 13 & 65 & 15 & 75 \\
\hline Cukup & 7 & 35 & 4 & 20 \\
\hline Kurang baik & 0 & 0 & 1 & 5 \\
\hline Total & 20 & 100 & 20 & 100 \\
\hline
\end{tabular}

besar $(70 \%)$ adalah pemuda yang berumur 18-65 tahun. Sebanyak 52,5\% responden berjenis kelamin laki-laki. Pendidikan terakhir dari sebagian besar responden (30\%) adalah Sekolah Menengah Pertama (SMP). Sebanyak 52,5\% dari responden bekerja di sektor pertanian. Sikap sebagian besar responden terhadap upaya pencegahan malaria sudah baik.

Hal ini ditunjukkan dengan persentase responden yang bersikap baik terhadap upaya pencegahan malaria mencapai $70 \%$. Jika dilihat dari pendidikan dan tingkat pendapatan, dan sebagian besar responden mempunyai pendapatan sedang, yaitu berkisar antara 250.000-750.000 rupiah per bulan.

Berdasarkan Tabel 2 diketahui bahwa sebagian besar responden yang menderita malaria yaitu 19 orang $(95 \%)$ dan responden yang tidak menderita malaria (70\%) mempunyai kesamaan dalam hal terbiasa berada di luar rumah saat malam hari. Hasil analisis bivariat terhadap kebiasaan berada di luar rumah malam hari menunjukkan bahwa nilai $p=0,065$. Hal ini mengindikasikan bahwa tidak terdapat hubungan yang bermakna antara kebiasaan berada di luar rumah malam hari dengan kejadian malaria di Desa Sudorogo Kecamatan Kaligesing Kabupaten Purworejo. Akan tetapi, kebiasaan berada di luar rumah ini merupakan faktor risiko terjadinya malaria di Desa Sudorogo Kecamatan Kaligesing Kabupaten Purworejo.

Kebiasaan pemakaian kelambu di wilayah penelitian masih belum merata. Sebagian besar responden yang menderita malaria tidak pernah menggunakan kelambu saat tidur malam, yaitu sebanyak 11 orang (55\%), sedangkan pada kelompok kontrol sebagian besar responden (85\%) sudah membiasakan menggunakan kelambu pada saat tidur malam. Hasil analisis bivariat terhadap kebiasaan menggunakan kelambu saat tidur malam, menunjukkan nilai $p=0,012$. Hal ini berarti bahwa kebiasaan menggunakan kelambu saat tidur malam mempunyai hubungan yang bermakna dengan kejadian malaria di Desa Sudorogo Kecamatan Kaligesing Kabupaten Purworejo. Berdasarkan penelitian ini, orang yang tidak menggunakan kelambu 
Tabel 2. Hubungan Tindakan Pencegahan dengan Kejadian Malaria di Desa Sudorogo Kecamatan Kaligesing Kabupaten Purworejo Periode Januari-Juli 2016

\begin{tabular}{|c|c|c|c|c|c|c|}
\hline \multirow{3}{*}{ Variabel } & \multicolumn{4}{|c|}{ Kejadian malaria } & \multirow{3}{*}{$p$} & \multirow{3}{*}{ OR } \\
\hline & \multicolumn{2}{|c|}{ Sakit } & \multicolumn{2}{|c|}{$\begin{array}{l}\text { Tidak } \\
\text { sakit }\end{array}$} & & \\
\hline & f & $\%$ & f & $\%$ & & \\
\hline \multicolumn{7}{|c|}{ Kebiasaan berada di luar rumah malam hari } \\
\hline Ya & 19 & 95 & 14 & 70 & \multirow{3}{*}{0,065} & \multirow{3}{*}{8,143} \\
\hline Tidak & 1 & 5 & 6 & 30 & & \\
\hline Total & 20 & 100 & 20 & 100 & & \\
\hline \multicolumn{7}{|c|}{ Kebiasaan memakai kelambu saat tidur malam } \\
\hline Ya & 9 & 45 & 17 & 85 & \multirow{3}{*}{0,012} & \multirow{3}{*}{6,926} \\
\hline Tidak & 11 & 55 & 3 & 15 & & \\
\hline Total & 20 & 100 & 20 & 100 & & \\
\hline \multicolumn{7}{|c|}{ Kebiasaan memakai obat anti nyamuk saat tidur malam } \\
\hline Ya & 13 & 65 & 16 & 80 & \multirow{3}{*}{0,293} & \multirow{3}{*}{2,154} \\
\hline Tidak & 7 & 35 & 4 & 20 & & \\
\hline Total & 20 & 100 & 20 & 100 & & \\
\hline \multicolumn{7}{|c|}{$\begin{array}{l}\text { Kebiasaan memakai repellent saat aktivitas di luar } \\
\text { rumah malam hari }\end{array}$} \\
\hline Ya & 8 & 40 & 13 & 65 & \multirow{3}{*}{0,117} & \multirow{3}{*}{2,786} \\
\hline Tidak & 12 & 60 & 7 & 35 & & \\
\hline Total & 20 & 100 & 20 & 100 & & \\
\hline \multicolumn{7}{|c|}{$\begin{array}{l}\text { Kebiasaan menggunakan baju lengan panjang dan } \\
\text { celana panjang saat keluar rumah malam hari }\end{array}$} \\
\hline Ya & 6 & 30 & 11 & 55 & \multirow[t]{3}{*}{0,114} & \multirow[t]{3}{*}{2,852} \\
\hline Tidak & 14 & 70 & 9 & 45 & & \\
\hline Total & 20 & 100 & 20 & 100 & & \\
\hline
\end{tabular}

pada saat tidur malam mempunyai risiko untuk menderita malaria sebesar 6,926 kali dibandingkan dengan orang yang terbiasa menggunakan kelambu saat tidur malam.

Kebiasaan pemakaian obat anti nyamuk pada saat tidur malam sudah baik. Berdasarkan Tabel 2, diketahui bahwa sebagian besar responden yang menderita malaria (65\%) dan tidak menderita malaria (80\%) sudah terbiasa menggunakan obat anti nyamuk saat tidur malam. Artinya, masyarakat sudah mulai menyadari bahwa pemakaian obat anti nyamuk saat tidur malam dapat mengurangi kemungkinan gigitan nyamuk. Hasil analisis bivariat terhadap kebiasaan penggunaan obat anti nyamuk pada saat tidur malam menunjukkan nilai $p=0,293$. Hal ini menunjukkan bahwa tidak terdapat hubungan yang signifikan antara kebiasaan memakai obat anti nyamuk saat tidur malam dengan kejadian malaria di Desa Sudorogo Kecamatan Kaligesing Kabupaten Purworejo. Meskipun demikian, nilai Ods Ratio (OR) dari kebiasaan penggunaan obat anti nyamuk menunjukkan bahwa variabel tersebut merupakan faktor risiko terjadinya malaria di wilayah penelitian.

Penggunaan repellent juga merupakan salah satu upaya untuk mengurangi gigitan nyamuk. Pemakaiannya sangat mudah terutama jika akan beraktivitas di luar rumah malam hari. Berdasarkan Tabel 2, diketahui bahwa sebagian besar responden yang menderita malaria $(60 \%)$, tidak pernah menggunakan repellent saat keluar rumah malam hari. Hasil analisis menggunakan uji regresi logistik sederhana menunjukkan nilai $p=0,117$. Hal ini menunjukkan bahwa tidak terdapat hubungan yang signifikan antara kebiasaan menggunakan repellent saat keluar rumah malam hari dengan kejadian malaria di Desa Sudorogo Kecamatan Kaligesing Kabupaten Purworejo. Meskipun hasil signifikansi tidak menunjukkan adanya hubungan yang bermakna, namun 
berdasarkan nilai OR diketahui bahwa tidak menggunakan repellent saat beraktivitas di luar rumah malam hari merupakan faktor risiko terjadinya malaria di wilayah penelitian.

Penggunaan baju lengan panjang dan celana panjang saat akan beraktivitas di luar rumah malam hari masih belum menjadi suatu kebiasaan bagi responden. Hasil analisis bivariat terhadap variabel kebiasaan memakai baju lengan panjang dan celana panjang saat keluar rumah malam hari menunjukkan nilai $p$ sebesar 0,114 . Hasil ini mengindikasikan bahwa kebiasaan memakai baju lengan panjang dan celana panjang saat keluar rumah malam hari tidak mempunyai hubungan yang bermakna dengan kejadian malaria di Desa Sudorogo Kecamatan Kaligesing Kabupaten Purworejo. Meskipun tidak mempunyai hubungan yang bermakna, akan tetapi tidak menggunakan baju lengan panjang dan celana panjang saat beraktivitas di luar rumah malam hari merupakan faktor risiko terjadinya malaria di wilayah penelitian.

Berdasarkan hasil wawancara dengan responden, diketahui bahwa seluruh responden telah terbiasa melakukan upaya penyehatan lingkungan. Kegiatan yang dilakukan adalah membersihkan semaksemak di sekitar rumah, membersihkan area kandang ternak dan melakukan kerja bakti. Kegiatan kerja bakti dilakukan secara rutin satu kali setiap minggu, sedangkan kegiatan pembersihan kandang ternak dilakukan setiap hari. Selain melakukan upaya penyehatan lingkungan, seluruh responden juga telah terbiasa menutup pintu dan jendela saat mulai senja. Hal ini dilakukan untuk mengantisipasi agar nyamuk penular malaria tidak masuk ke dalam rumah. Masuknya nyamuk ke dalam rumah tidak hanya melalui jendela atau pintu saja, akan tetapi dapat juga melalui lubang ventilasi atau lubang pertukaran udara. Berdasarkan pengamatan atau observasi langsung yang telah dilakukan, diketahui bahwa seluruh rumah responden baik kelompok kasus maupun kelompok kontrol belum terpasang kawat kasa pada lubang pertukaran udara seperti ventilasi, jendela maupun pintu.

\section{PEMBAHASAN}

Perilaku responden dalam beraktivitas di luar rumah malam hari didukung karena adanya kegiatan keagamaan yang dilakukan secara bergilir dari rumah ke rumah setiap minggunya. Selain itu, ada juga yang sekedar pergi ke warung membeli kebutuhan dan pergi menonton televisi ke rumah tetangga. Kegiatan rutin lainnya yang dilakukan saat malam hari adalah shalat berjamaah di mushola. Berbagai kebiasaan ini dapat mempermudah terjadinya kontak dengan nyamuk penular malaria. Hal ini sesuai dengan yang telah dijelaskan dalam Kemenkes (2014) bahwa kebiasaan berada di luar rumah sampai larut malam dapat mempermudah kontak dengan nyamuk penular malaria, apalagi nyamuk yang memang sifatnya lebih suka beristirahat dan menggigit di luar rumah. Beberapa jenis nyamuk Anopheles yang ada di wilayah penelitian yaitu An. aconitus, An. balabacencis, dan An. maculatus. Menurut Natadisastra \& Agoes (2009) nyamuknyamuk tersebut mempunyai sifat lebih senang beristirahat dan menggigit di luar rumah.

Selain hal tersebut, masih terdapat beberapa responden yang lokasi kamar mandi atau jambannya memang terpisah dengan rumah bahkan masih terdapat keluarga yang tidak mempunyai jamban, sehingga kegiatan buang air besar dilakukan di sungai. Keadaan inilah yang mengharuskan responden untuk keluar rumah jika ada keperluan ke kamar mandi atau jamban. Seperti yang dijelaskan oleh Notoatmodjo (2010) bahwa meskipun seseorang memahami atau mempunyai sikap yang baik terhadap suatu hal akan tetapi belum serta merta pemahaman tersebut terwujud dalam tindakan sehari-hari. Hal ini disebabkan karena untuk mewujudkan sikap menjadi tindakan dibutuhkan adanya faktor pendukung, yaitu adanya fasilitas dan dukungan. Pada kasus ini, beberapa responden yang masih terbiasa keluar rumah dikarenakan belum mempunyai fasilitas seperti televisi maupun kamar mandi atau jamban yang lokasinya menjadi satu bagian dengan rumah. 
Hasil dalam penelitian ini sejalan dengan penelitian yang dilakukan oleh Santy et al (2014) bahwa tidak terdapat hubungan yang signifikan antara kebiasaan berada di luar rumah malam dengan kejadian malaria. Berbeda dengan hasil penelitian dari Santoso \& Karbito (2013). Pada penelitiannya, didapatkan hasil bahwa seseorang akan berisiko terkena penyakit malaria sebesar 2,71 kali jika mempunyai kebiasaan berada di luar rumah dibandingkan dengan seseorang yang tidak terbiasa berada di luar rumah malam hari.

Penggunaan kelambu saat tidur malam merupakan salah satu upaya penting dalam mencegah dari gigitan nyamuk penular malaria. Pada penelitian ini, sebanyak 55\% responden yang menderita malaria tidak menggunakan kelambu saat tidur malam. Sebagian besar responden menuturkan alasan mereka tidak menggunakan kelambu saat tidur malam adalah mereka merasa tidak nyaman jika tidur menggunakan kelambu. Penggunaan kelambu membuat suasana tidur menjadi panas atau gerah. Oleh karena itu, penggunaan kelambu hanya digunakan pada saat-saat tertentu saja, misalnya jika dirasa nyamuknya banyak. Hal ini sangat disayangkan karena penggunaan kelambu dapat meminimalkan terjadinya kontak dengan nyamuk Anopheles penular malaria.

Hasil pada penelitian ini sejalan dengan penelitian yang dilakukan oleh Priyandina (2011) yang menyatakan bahwa seseorang akan berisiko 3,5 kali terkena malaria jika tidak menggunakan kelambu saat tidur. Pada penelitian Harmendo (2008) juga didapatkan hasil yang sama bahwa pemakaian kelambu pada saat tidur malam berhubungan dengan kejadian malaria. Orang yang tidak memakai kelambu saat tidur malam mempunyai risiko 7,8 kali untuk terkena penyakit malaria dibanding orang yang mempunyai kebiasaan memakai kelambu saat tidur malam. Pada penelitian Santoso \& Karbito (2013), dipaparkan bahwa terdapat hubungan antara pemakaian kelambu saat tidur malam hari dengan kejadian malaria dengan ( $\mathrm{p}$-value $=0,000)$ dan OR 5,842 (95\% CI : 2,7412,46). Ahmadi (2008) juga menuturkan bahwa kebiasaan menggunakan kelambu mempunyai hubungan yang bermakna dengan kejadian malaria. Seseorang yang tidak menggunakan kelambu berisiko 4,060 kali terkena malaria dibandingkan dengan yang menggunakan kelambu.

Banyak penelitian yang menyatakan adanya hubungan antara kebiasaan menggunakan kelambu dengan kejadian malaria. Meskipun demikian, hal ini berbeda dengan hasil penelitian milik Anjasmoro (2013). Hasil penelitiannya menyatakan bahwa tidak terdapat hubungan antara penggunaan kelambu dengan kejadian malaria di wilayah kerja Puskesmas Rembang Kabupaten Purbalingga.

Pemakaian obat anti nyamuk saat tidur malam sudah dilakukan oleh sebagian besar responden baik pada kelompok yang menderita malaria maupun kelompok yang tidak menderita malaria. Jenis obat anti nyamuk yang paling banyak digunakan adalah jenis obat anti nyamuk bakar dan sebagian menggunakan lotion anti nyamuk. Responden yang sudah terbiasa menggunakan obat anti nyamuk saat tidur memberikan gambaran bahwa mereka sudah menyadari akan bahaya dari penyakit malaria, sehingga pemahaman tersebut mereka wujudkan dalam tindakan yaitu melakukan proteksi diri dari gigitan nyamuk penular malaria, salah satunya dengan menggunakan obat anti nyamuk saat tidur malam. Meskipun demikian, masih terdapat beberapa responden yang tidak menggunakan obat anti nyamuk saat tidur malam. Beberapa alasan yang diungkapkan adalah masalah asap dan bau yang tidak sedap. Selain itu, pemakaian lotion anti nyamuk atau repellent juga dirasa kurang nyaman, karena terkadang setelah menggunakan repellent, responden masih ingin mengonsumsi makanan.

Hasil pada penelitian ini sejalan dengan penelitian yang dilakukan Harmendo (2008) bahwa tidak terdapat hubungan yang bermakna antara pemakaian obat anti nyamuk saat tidur dengan kejadian malaria. Penelitian yang dilakukan oleh Anjasmoro (2013) di wilayah kerja Puskesmas Rembang Kabupaten Purbalingga juga menunjukkan hal yang sama bahwa tidak terdapat hubungan antara pemakaian obat anti nyamuk dengan kejadian malaria. Namun, penelitian Santy et al (2014) menyatakan 
hal yang berbeda. Pada penelitiannya, dijelaskan bahwa seseorang yang tidak memakai obat anti nyamuk saat tidur malam mempunyai risiko tertular penyakit malaria sebesar 2,17 kali dibandingkan dengan yang memakai obat anti nyamuk saat tidur. Penelitian Santoso \& Karbito (2013), juga menerangkan bahwa terdapat hubungan antara penggunaan obat anti nyamuk dengan kejadian malaria. Seseorang yang tidak menggunakan obat anti nyamuk berisiko 2,40 kali terkena malaria dibandingkan dengan orang yang menggunakan obat anti nyamuk.

Salah satu upaya pencegahan terhadap gigitan nyamuk pembawa malaria adalah dengan menggunakan repellent atau lotion anti nyamuk pada saat akan beraktivitas di luar rumah malam hari. Penggunaan repellent dianggap praktis untuk dipakai saat akan ada kegiatan di luar rumah malam hari (Kemenkes, 2014). Meskipun demikian, berbeda dengan kebiasaan responden di wilayah penelitian. Beberapa responden belum membiasakan menggunakan repellent pada saat beraktivitas di luar rumah malam hari. Penggunaan repellent dirasa tidak efektif karena pemakaian repellent hanya dioleskan di bagian tangan dan kaki saja, sedangkan masih terdapat area lain yang masih memungkinkan untuk digigit nyamuk pembawa malaria. Hasil penelitian ini sejalan dengan penelitian Arjunah (2012) bahwa tidak ditemukan hubungan yang bermakna antara penggunaan obat anti nyamuk saat berada di luar rumah malam dengan kejadian malaria.

Selain penggunaan repellent, upaya proteksi diri ketika beraktivitas di luar rumah juga dapat dilakukan dengan menggunakan baju lengan panjang dan celana panjang. Akan tetapi, hal ini masih belum menjadi suatu kebiasaan bagi responden di wilayah penelitian. Responden menuturkan sudah terbiasa tidak menggunakan baju lengan panjang dan celana panjang saat keluar rumah malam, kecuali untuk kegiatan tertentu seperti pengajian dan pergi ke mushola. Hasil penelitian ini sejalan dengan penelitian Arjunah (2012) bahwa tidak terdapat hubungan yang bermakna antara perilaku proteksi pribadi dengan kejadian malaria.
Kegiatan penyehatan lingkungan sangat perlu dilakukan. Kegiatan ini bertujuan untuk mengurangi bahkan menghilangkan keberadaan tempat perindukan dan tempat peristirahatan nyamuk Anopheles. Seluruh responden telah melakukan kegiatan penyehatan lingkungan setiap minggunya. Kegiatan yang dilakukan diantaranya adalah membersihkan area kandang ternak, membersihkan semak-semak yang digunakan sebagai tempat peristirahatan nyamuk Anopheles dan kerja bakti membersihkan saluran air atau parit maupun jalan. Kegiatan kerja bakti tidak dapat berjalan lancar tanpa adanya kerja sama atau dukungan dari seluruh lapisan masyarakat. Hal ini sesuai dengan yang diungkapkan Notoatmodjo (2010) bahwa diperlukan adanya dukungan (support) untuk dapat mewujudkan suatu tindakan. Meskipun demikian, masih terjadi kasus malaria di wilayah penelitian. Hal ini dapat disebabkan karena beberapa responden masih melakukan kebiasaan yang berpotensi kontak dengan nyamuk malaria yaitu kebiasaan berada di luar rumah malam hari, kebiasaan tidak menggunakan kelambu saat tidur malam, kebiasaan tidak menggunakan obat anti nyamuk saat tidur malam serta tidak menggunakan repellent saat beraktivitas di luar rumah malam hari.

Seluruh responden di lokasi penelitian sudah terbiasa menutup pintu dan jendela saat senja, sehingga besarnya risiko kebiasaan menutup pintu dan jendela tidak dapat dianalisis. Meskipun seluruh responden sudah terbiasa menutup pintu dan jendela, hal ini tidak menutup kemungkinan untuk dapat terjadi kontak dengan nyamuk penular malaria. Nyamuk Anopheles masih dapat masuk ke dalam rumah melalui lubang ventilasi maupun celah dinding, serta langitlangit rumah. Apalagi beberapa rumah responden memang merupakan bangunan yang belum permanen dan belum terpasang kasa pada lubang pertukaran udara.

Pada penelitian Harmendo (2008), didapatkan hasil bahwa tidak terdapat hubungan yang bermakna antara kebiasaan menutup pintu dan jendela dengan kejadian malaria di wilayah Puskesmas Kenanga Kecamatan Sungailiat Kabupaten Bangka. Hal ini berbeda dengan penelitian dari Arjunah (2012). Hasil penlitian Arjunah 
(2012) menunjukkan ada hubungan yang signifikan antara modifikasi perilaku yang meliputi mengurangi aktivitas di luar rumah, menggunakan kipas angin untuk mengusir nyamuk, menutup pintu dan jendela serta menggunakan kelambu dengan kejadian malaria di Kabupaten Mamuju Utara.

Pemasangan kawat kasa pada lubang pertukaran udara seperti pintu, jendela dan ventilasi merupakan salah satu langkah untuk membatasi masuknya nyamuk penular malaria ke dalam rumah. Sesuai dengan hasil observasi yang dilakukan, diketahui bahwa tidak ditemukan keberadaan kawat kasa pada seluruh rumah responden, baik yang menderita malaria maupun yang tidak menderita malaria. Meskipun seluruh responden telah sepakat bahwa pemasangan kawat kasa pada lubang pertukaran udara dapat membatasi masuknya nyamuk penular malaria ke dalam rumah, akan tetapi sikap ini belum terwujud dalam tindakan nyata. Hal ini erat kaitannya dengan ada atau tidaknya faktor pendukung seperti yang disampaikan oleh Notoatmodjo (2010). Faktor ekonomi menjadi alasan mengapa responden belum memasang kawat kasa pada lubang pertukaran udara. Responden menuturkan bahwa kebutuhan untuk memasang kawat kasa belum menjadi prioritas. Hal ini karena masih ada kebutuhan lain yang harus mereka penuhi yaitu kebutuhan pokok sehari-hari dan biaya sekolah anak.

Hasil pada penelitian ini sama dengan kejadian malaria di wilayah kerja Puskesmas Biluhu Kabupaten Gorontalo yang diteliti oleh Ibrahim (2013). Hasil penelitiannya juga menunjukkan risiko dari variabel keberadaan kawat kasa tidak dapat dianalisis karena $100 \%$ responden tidak memiliki kawat kasa. Penelitian Santoso \& Karbito (2013) juga menunjukkan hal yang sama bahwa seluruh responden dalam penelitiannya tidak menggunakan kawat kasa. Akan tetapi, hal ini berbeda dengan penelitian Arjunah (2012). Hasil penelitiannya menjelaskan adanya hubungan yang bermakna antara keberadaan kawat kasa dengan kejadian malaria dengan nilai $p$ sebesar 0,001 . Pada penelitian Priyandina (2011) diketahui bahwa seseorang yang tinggal di rumah yang tidak mempunyai kasa, mempunyai risiko 3,9 kali terkena malaria dibandingkan dengan seseorang yang tinggal di rumah yang dipasang kawat kasa.

\section{KESIMPULAN}

Berdasarkan analisis yang telah dilakukan, dapat diambil kesimpulan bahwa tindakan pencegahan malaria yang meliputi kebiasaan berada di luar rumah malam, kebiasaan tidak memakai obat anti nyamuk saat tidur malam, kebiasaan tidak memakai repellent saat beraktivitas di luar rumah malam dan kebiasaan tidak menggunakan baju lengan panjang dan celana panjang tidak mempunyai hubungan yang bermakna dengan kejadian malaria di Desa Sudorogo Kecamatan Kaligesing Kabupaten Purworejo. Akan tetapi, keempat variabel tersebut merupakan faktor risiko terjadinya malaria di wilayah penelitian. Variabel yang mempunyai hubungan signifikan dengan kejadian malaria di Desa Sudorogo Kecamatan Kaligesing Kabupaten Purworejo adalah kebiasaan tidak menggunakan kelambu saat tidur malam.

Masyarakat diharapkan lebih proaktif terhadap upaya pencegahan penyakit malaria seperti membiasakan ketika tidur malam menggunakan kelambu atau obat anti nyamuk, dan jika memang harus melakukan kegiatan di luar rumah malam sebaiknya menggunakan baju lengan panjang dan celana panjang dan atau memakai lotion anti nyamuk. Hal ini erat kaitannya dengan jenis nyamuk Anopheles yang banyak ditemukan di wilayah kerja Puskesmas Kaligesing adalah spesies yang cenderung lebih aktif di luar rumah pada malam hari sampai menjelang pagi hari.

\section{DAFTAR PUSTAKA}

Ahmadi, S. 2008. Faktor Risiko Kejadian Malaria di Desa Lubuk Nipis Kecamatan Tanjung Agung Kabupaten Muara Enim. Tesis. Semarang: Universitas Diponegoro.

Anjasmoro, R. 2013. Faktor-Faktor yang Berhubungan dengan Kejadian Malaria di Wilayah Kerja Puskesmas Rembang Kabupaten Purbalingga. Jurnal Kesehatan 
Masyarakat,Vol.2, No. 1.Tersedia di:http:// eprints.undip.ac.id/38864/1/4545.pdf [30Januari 2017].

Anonim. 2016. Inilah Fakta Keberhasilan Pengendalian Malaria. Jakarta: Tersedia di: http://www.depkes.go.id/article/ view/16050200003/inilah-faktakeberhasilan-pengendalian-malaria.html. [Diakses 25 Januari 2017].

Arjunah, 2012. Hubungan Perilaku Masyarakat tentang Pencegahan dengan Kejadian Malaria di Kabupaten Mamuju Utara Sulawesi Barat. Skripsi. Makassar: Universitas Hassanudin.

Asmadi. 2008. Konsep Dasar Keperawatan. Jakarta: EGC.

BPS Purworejo. 2016. Statistik Daerah Kecamatan Kaligesing 2016. Purworejo: Badan Pusat Statistik.

Dinkes Jateng. 2014. Profil Kesehatan Provinsi Jawa Tengah Tahun 2014. Semarang: Dinkes Jateng. Tersedia di: http://www.dinkesjatengprov.go.id/ v2015/dokumen/profil2014/Profil_2014. pdf [16 Mei 2016].

Dinkes Jateng. 2015. Profil Kesehatan Provinsi Jawa Tengah Tahun 2015. Semarang: Dinkes Jateng. Tersedia di: http://dinkesjatengprov.go.id/v2015/ dokumen/profil2015/Profil_2015_fix.pdf [25 Januari 2017].

Ditjen Pengendalian Penyakit dan Penyehatan Lingkungan. 2015. Rencana Aksi Program Pengendalian Penyakit dan Penyehatan Lingkungan Tahun 2015-2019. Jakarta: Direktorat Jenderal Pengendalian Penyakit dan Penyehatan Lingkungan

DKK Purworejo. 2013. Profil Dinas Kesehatan Kabupaten Purworejo Tahun 2013. Purworejo: Dinas Kesehatan Kabupaten Purworejo.

DKK Purworejo. 2014. Profil Dinas Kesehatan Kabupaten Purworejo Tahun 2014. Purworejo: Dinas Kesehatan Kabupaten Purworejo.

DKK Purworejo. 2016. Laporan Bulanan Register Malaria. Purworejo: Dinas Kesehatan Kabupaten Purworejo.

Harmendo. 2008. Faktor Risiko Kejadian Malaria di Wilayah Kerja Puskesmas
Kenanga Kecamatan Sungailiat Kabupaten Bangka. Tesis. Universitas Diponegoro.

Ibrahim, Y.A.T. 2013. Faktor Risiko Sanitasi Lingkungan Rumah terhadap Kejadian Malaria di Wilayah Kerja Puskesmas Biluhu Kabupaten Gorontalo tahun 2013. Skripsi. Universitas Negeri Gorontalo.

Kemenkes. 2011. Epidemiologi Malaria di Indonesia. Jakarta: Kementerian Kesehatan RI.

Kemenkes. 2012. Buku Saku Penatalaksanaan Kasus Malaria. Jakarta: Ditjen Pengendalian Penyakit dan Penyehatan Lingkungan Kementerian Kesehatan RI.

Kemenkes. 2014. Pedoman Manajemen Malaria. Jakarta: Kementerian Kesehatan RI.

Kemenkes. 2016. Infodatin Malaria. Jakarta: Pusat Data dan Informasi Kementerian Kesehatan RI.

Maulana, H.D.J. 2009. Promosi Kesehatan. Jakarta: EGC

Notoatmodjo, S. 2010. Promosi Keehatan. Jakarta: Rineka Cipta.

Pemerintah Kabupaten Purworejo. 2016. Rencana Kerja Pemerintah Daerah (RKPD) Kabupaten Purworejo Tahun 2016. Tersedia di: http://www. purworejokab.go.id [20 Juni 2016].

Priyandina, A.R. 2011. Pengaruh lingkungan dan perilaku terhadap kejadian malaria di wilayah kerja Puskesmas Sanggau Kecamatan Kapuas Kabupaten Sanggau. Skripsi. Universitas Tanjungpura.

Santoso, H.B. \& Karbito. 2013. Perilaku Masyarakat dan Kejadian Malaria di Desa Pulau Legundi Kecamatan Punduh Pedada Kabupaten Pesawaran. Jurnal Kesehatan. IV (1): pp.391-400.

Santy, Fitriangga, A. \& Natalia, D. 2014. Hubungan faktor individu dan lingkungan dengan kejadian malaria di desa Sungai Ayah 3 Kecamatan Belitang Hilir, Kabupaten Sekadau. Naskah Publikasi. Universitas Tanjungpura.

Soedarto. 2009. Pengobatan Penyakit Parasit. Jakarta: CV. Sagung Seto.

Subekti, R. 2016. Kasus Malaria di Indonesia Sudah Menurun. Tersedia di: http:// 
pojoksatu.id/lipsus/2016/04/30/kasusmalaria-di-indonesia-sudah-menurun/ [16 Juni 2016].

Sutriyanto, E. 2014. 80 Persen Kasus Malaria di Indonesia Ada di 5 Provinsi Ini. Tersedia di: http://www.tribunnews.com/ kesehatan/2014/04/26/80-persen-kasusmalaria-di-indonesia-ada-di-5-provinsiini [20 Juni 2016].

WHO. 2014. Fact sheet Malaria. [pdf] Geneva:WHO. Tersedia di: http://www.searo. who.int/entity/world_health_day/2014/ Malaria_factsheet_A4.pdf [20 Juni 2016].

WHO, 2015. World Malaria Report 2015. [pdf] Geneva: World Health Organization. Tersedia di: http://www.who.int/malaria/ publications/world-malaria-report-2015/ report/en/ [15 Juni 2016].

Widoyono. 2011. Penyakit Tropis: Epidemiologi, Penularan, Pencegahan \& Pemberantasannya. Kedua ed. Jakarta: Penerbit Erlangga. 